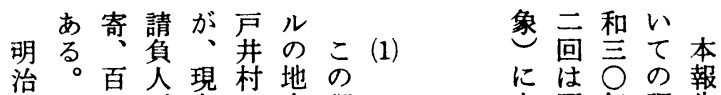

治 姓が在の点調一一未昭年調告

年代あの開に查般名和八查は、

開小七役基位置行治部実四月結二

拓頭運場道しっ 落し年刕息度

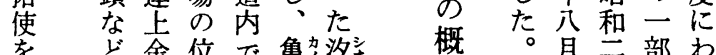

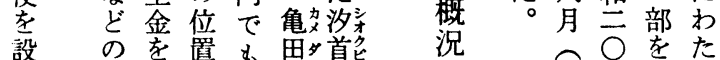

置

置役徴に古郡部

乙集館古㫃卜落

以 おし、築、开村は

来文心䋉に函

昭年とっ

和入りて

三月行

○)とつ

年昭めた

明村年と政駅

八和た 漁

治治間い○るか

$\nmid \bar{\bigcirc}$ の村

昭 年で家

吾留はれわ年渻東

和七あ族

年意会、落南

四月るお

二 せ亲近岡の

○范

年 移 第 び

七動一人

町亡活初郎一五

月を回口

村 $心$ 、期左つキ

の対の調移

制う名に衛で口

移象調移

を、真に

に行録年に季る

対第昭

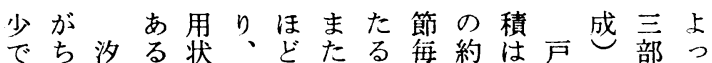
の首。況通しは函に分約井と落て 家海部な学て徒館来 $\bigcirc$ 六村にで、 庭岸落どやい歩市游パパは各構戸 菜ではの通るでとす、1総々成井 園あ、面勤。往のる七七面分し村 程る汐少に海来つ寄ンン積離とと 度。首らは岸しな魚卜卜の独六し に背岬、無うてが漁近で大立井て 過後の函理たいり業く、部し村統 ぎに突館でいたはを、農分て 合 す急端市あの染主伝業がい瀬をさ 、傾ににる狭、昔体統へ、た田动

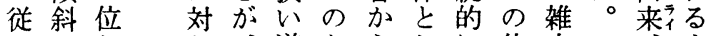
っのしし、道ちらしに依㷊来京 て山、て日道密て地存よ 漁を外、常でス接き先度り 業控洋都物、がでた磯はな へえに市資距開、沿浜小る のて直利の離通昭岸でさ山 依い面用購のし和漁のい林 存るし 圈入割、初村魚。で 度たたと、合現期で介漁占

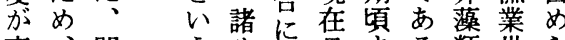
高、凹 ら茾に早まる類世ら

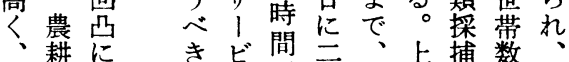
い地富関不が客級と浦 わはむ係のか往馬都、全地 流磯に利加復車市季体面

本守中

二歹安界村

兒三村

原今尔 禁安晨 の

四 金号

部

落 汐

で首

構 の

六

年

社

会

変

华
中
克
l 
図 1 戸井村の位置およびその区分

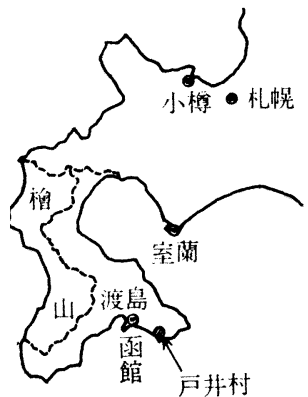

情館脯

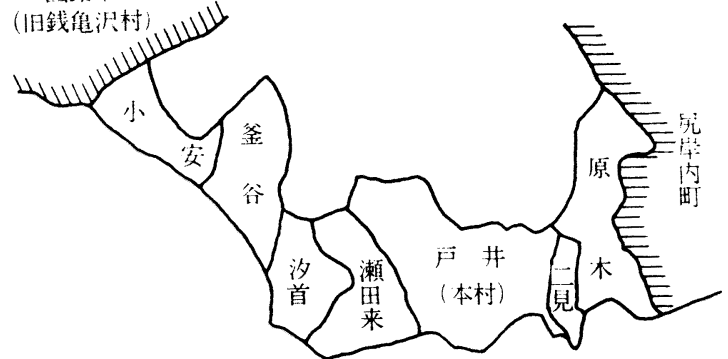

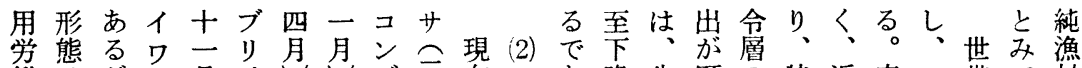

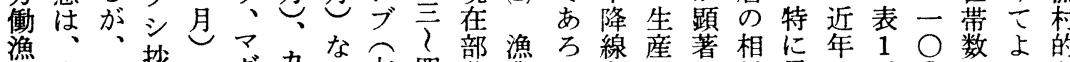

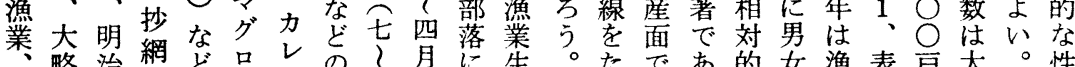

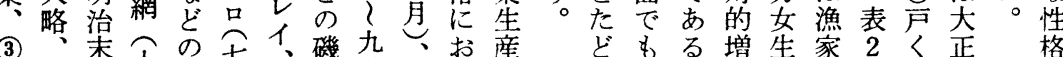

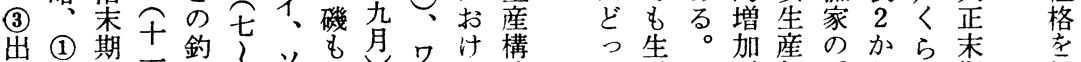

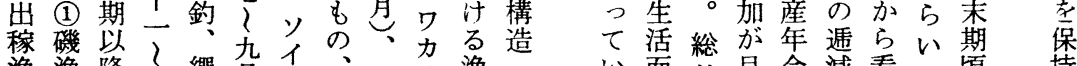

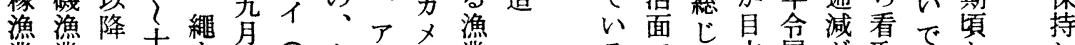

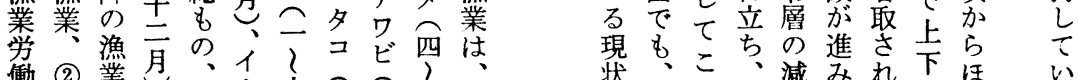

地活、お力公声六テ

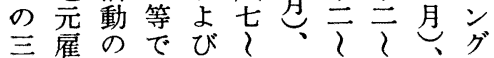

状、こ、減みれ下柏

上停の人少つるしぼる る

え滞部品落流あをでて完落

置漁で 漁こつ

網業行漁れに

元とう番に区

にがも者は分

雇あの齐吉

用ると萦口る

さ。、資あこ

れ(2)今凅け少

も1つ漁口で

のワは漁どき

と、シ、各䚀める。

イサ自模な (1)

力バ由渙どは

、なに鮕の部

ブど出具部落

リの漁漁落地

、来 し法統 先

マ游て採制海

グ接、採に面

口岸釣捕服を

な時 や時 し 漁

ど期繩等、場

やに等各先

や部る制平る

沖落小限等 を

合内規あなの

のの模り条で

魚定な已件

表 1 世帯および人口

\begin{tabular}{l|c|c}
\hline & 昭和 30 年 8 月 & 昭和 40 年 8 月 \\
\hline 1. 世帯総数 & 118 & 112 \\
2. 職業別世帯数 & & \\
漁業専業および第1 種兼業 & 99 & 84 \\
第2 種兼業 & 7 & 9 \\
$\quad$ 非漁家 & 12 & 19 \\
3. 総人口 & 752 & 629 \\
$\quad$ 男 & 370 & 312 \\
女 & 382 & 317 \\
女. 男女別年令階層別人口 & & \\
$0 \sim 14$ 才 & 138 & 111 \\
$15 \sim 59$ & 200 & 166 \\
$60 \sim$ & 32 & 35 \\
男 & 142 & 124 \\
$5 \sim 14$ & 214 & 157 \\
$15 \sim 59$ & 26 & 36 \\
$60 \sim$ & &
\end{tabular}

\footnotetext{
（註）（1）明 30 の 2 兼漁家内訳は

商業一漁業 5, 公務一漁業 1, 大工一漁業 1

(2) 昭 30 の非漁家内訳

公務 5 , 商業 5 , 士木学務 2

（3）昭 40 の 2 兼漁家内訳は土木学務一漁業 9

（4）昭 40 の非漁家内訳は

公務 4, 商業 6 , 土木労務 1 , 漁協襱員 1

床屋 1, 貸間 1 , 日雇 2 , 無硫 3
} 
抄変漁 $\bigcirc$ 較種

網遷業々ま 年と的に

のっにこず以こ閑つ

漁従み第降乃漁い

法来ら-そでのて

とのれはの約時

な定る、内五期部

置変久容 ○に落

た網化しに年な内

かでく著ほさ船

がらあ中しど主

、サる枢い継てに

まン。的変続い雇

たマイな化した用

イ棒ワ地がてもさ

力受シ位生きのれ

で網にをじたでて

はのつ保た前あ行

、様いっの記るう

そ式ててでの。も

のにはをあ漁の

主よ来たる。要告に

漁、游イ 夕叫

場灯のワ 1 分

が火減シヘささ

釧を少お゙桠

路利角漁び 昭 (3)

根し法 イ 和 は
表 2 世帯人口の変化

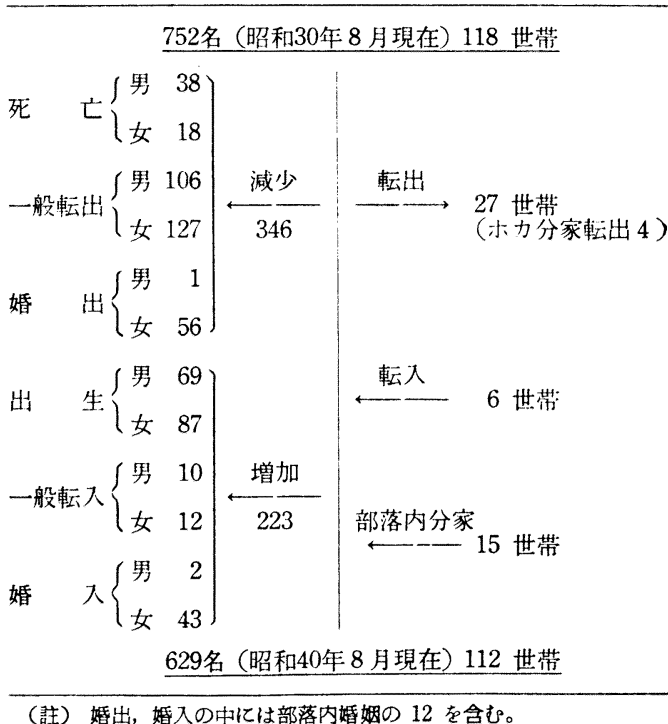

（註）婚出，婚入の中には部落内婚姻の 12 を含む。

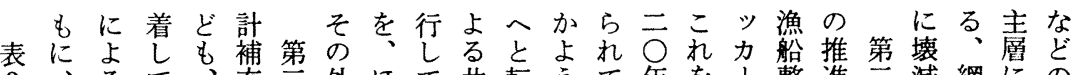
3 るて充至外ほて共転うて年を门整進兰隇網にの で土遠き近策に貌と、同換にいぶ駆船備すに状元大道 明杰洋た年と出をん無、船たり使地がる小態・き東 ら労漁。はい稼二ど動とた主、にしと、つ型と網な沖 枒業こ世う漁変の力いこ冬来た呼融治動な子打合 な柇へ带色業し磯船うと網季游漁は資岸力う、撃へ よ憇のを主彩労た舟の形に元のし業れの漁船た船亡、

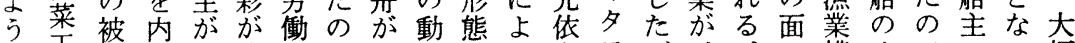
に場角容積濃ので装力につ存コブ、、で構めで・つ幅 場で的極厚性あ備積再ての漁りこ三優造ざあ乗たに

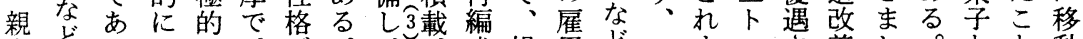

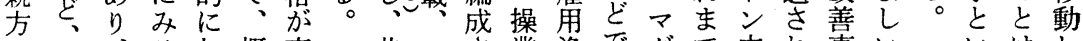
非、る加概変昔つさ業漁でグで末れ事い

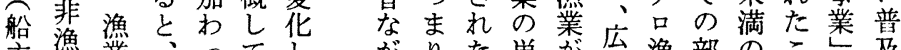
主業業、ってしがりた単が広漁部のこし及 網余学働主て世带た 元出者を恒竞従 增 $し し$ 的参は 磯只 傾てな加閑 舟貝向 生方漁 漁立向る゙業少期

師つ窥䆓の活なに

無き热湩かお

動でる大したる 力いる資てける 船る。本定れ家く機平に業る。限、、十の道

ら小。位、汎渠落小亡の唯 の型な孚小之型々奉举 櫓のお、型そあ雇動相施げ やと動家動機る用力俟にら 櫂り力族力機以漁船っ伴れ に外船乃船動は業のている よし至を吕従に所 る可購小中登来亡有い一特 漁能入規心発沿っ者わ○に 法な、模と揮岸てがゆト国 は船使なして近か激るンお いはし ついた たう 伝な゙ 統 \& $し$ 的なた ない変 学。花 関 係部 定 は落置 内網

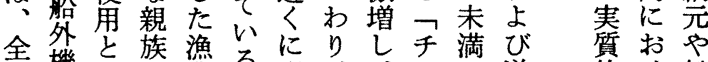

的计船 
会総な区地一い 表 3 経営規模別漁家階層

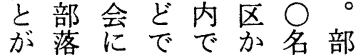

あ総代あのらの落

、会行る意評役会

部は得祭の員老は

落、る緊集学指

地年こ急約立名三

先間と時や名年

漁豆にに、名決毎

場回なは部つ定に

人乞つ評落選吉部

の二、儀税举る。落

\begin{tabular}{|c|c|c|}
\hline & 昭和 30 年 8 月 & 昭和 40 年 8 月 \\
\hline 1. 大型船主 $(10 \sim 20$ トン) & 6 & 2 \\
\hline 2: 定置網元 (単独) & 3 & - \\
\hline 3. 定置網元（共同） & 7 & - \\
\hline 4. 小型船主 ( 3 トン未満) & 12 & 40 \\
\hline 5. 無動力船漁家 & 70 & 46 \\
\hline 6. 漁業労働層漁家 & 8 & 5 \\
\hline 漁業従事世帯合計 & 108 & 93 \\
\hline
\end{tabular}

部七る員会るま会な間限ンのもう

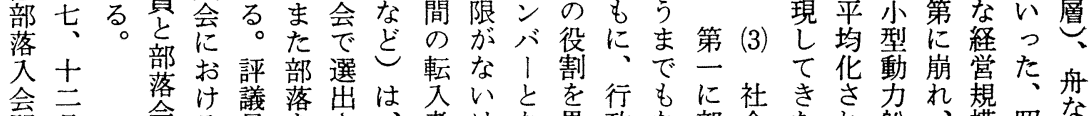

問月会る䛾哆さは、者けな果政な部会たれ船机模昭な

題貝決の三慣へれるた的く落集こた家別和し

のの 員定主三、習小どのし下、会団少階中族階望漁

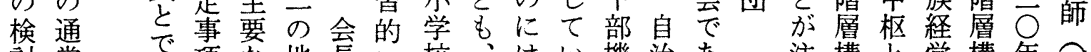

討常行項な地長に校、は、機治あ 注構と営構年 鮘

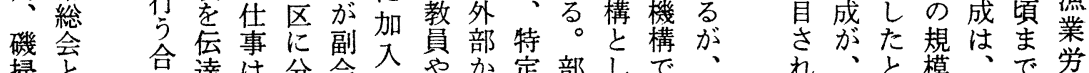

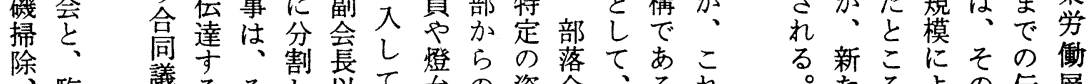

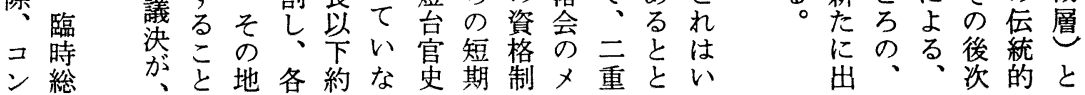

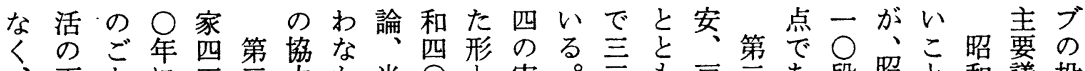

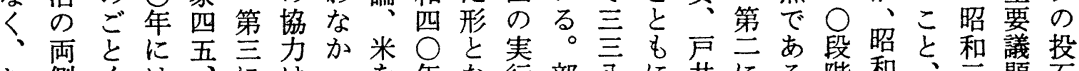

む側くは面でに棌本、た注でっ組落名に西漁。階和、西昭題石

ろにあ本分分か、じはて合内名部業

姻おつ家家家なコめ、以穴に本井、協

族いて二五、りン日預るあ組拠西戸同

間て、九撨ブ常金。り、合を部井組

で、そ、現よんな生がそ、の釜漁東合

の系の分存びでど活大のこ分谷業部に

相譜血家者姻きの用幅事れ室に協しつ

互少縁至に族た一品に業はを設同がい

扶本関九つ関と次のふ会前お置組あて

助末係、い係い製購え容述きさ合りみ

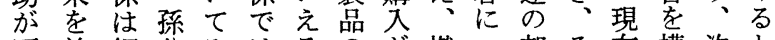

顕前網分みはる。の㤎燃つ部そ在構汐と、

著提状家た昭集著油い落の部成首巨

観し行六落和㤎く網、二部落釜井

察たき、内亥 円伸昭二に漁組谷村

さ渡部婚 $\overrightarrow{0}$ 滑び采和地第家合、に

れ同っ落姻年化、な至区—の員瀬は

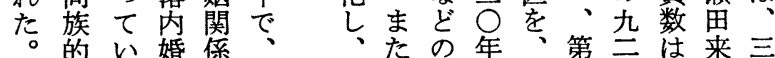

結了姻四本全従生亡ほ第文、皇

合。関三家般来産比ぼ、が昭両の

は生係一涂資較四第加和隣組

分産吾昭八組り材し等至入四接合

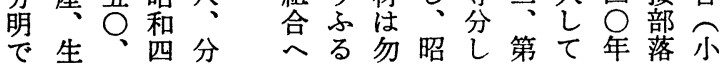

等 $\bigcirc$ 和年な道

級年悡とる路

宁に昭

けは年和

ら前当四

れ記 時 $\bigcirc$

てのよは年委

た致毎比共

のに年較

を簡会し

均易長、

等化以役所

割さ下員得

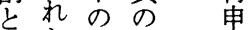

した全顔告

たこ役ぶ方

こと員れが式

な突余審

ぞ部し変

$\begin{array}{lll}\text { が貣でっ } & \text { 決 } \\ \text { 立寞た } & \text { 定 } \\ \text { 等 }\end{array}$

が 


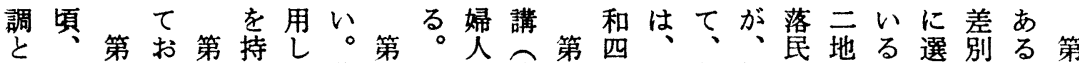
な北入牙参て葬公を浄五○昭部相が区。出やが四

り海に、のしい式にメさに年和落互参か祭さ制、に 道青各婦、るや壇棕講に亥間訪与ら典机限外氏

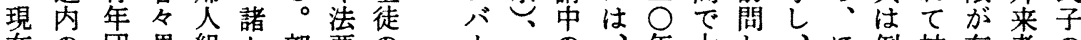
在の団異組々部要の1 で漁はな織の落の組と㵛組部当き合盛ほ年社在や組 は村、るで手内際織棰織落時く 5 大均七のし新織 祭青末分は伝で、に、講は会、意慣に等月管な分は 典年婚野、以誰夫関 時活ので組を名々し と動 男、合守死のて 汃異婦る亡宗は 表にな人のし派、 冬彰よる部がたに判 季さっメと普と応然 のれてン部通きじた

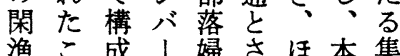
漁と成に婦さほ本集 折毛机全てん的 にあ、っといどか形 小っ昭てのる部、態 学た和活二。落隣は 校が二動本 の村見

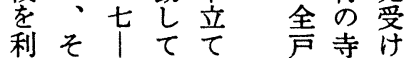
用の二いと院ら

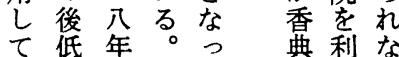
行祽的費上義例行に中理い家 わ祱昭と势にわ選旬に。に部 れ赤和同中けなれ出に当氏対落 てな三様、らっるす行り子し中

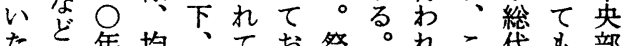
た主年均、抒。祭。こ代も部 が吾頃等のいり血祭、れ七、に そ類鬼と割等るると典そに名全位

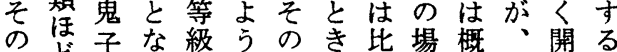
組克母つにで接に較合初部放洺 轼り神て区あ待は的、部落的首 は、講い分るは䦙祭落会で神 漸主講るさる格近漁典のの、社

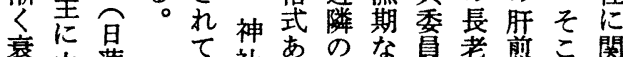

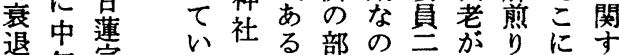
た勿行落で四選ではる

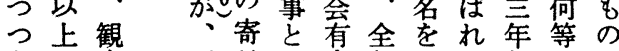
あの音 昭付し志部二て毎ので

$\stackrel{2}{2}$ 家題更然的次婦のた基。両慮家分の

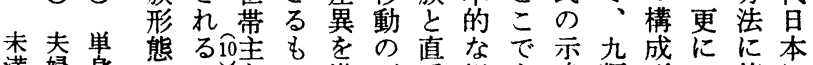
満婦身はこ者は織可系視主唆類形こ傍に の者文現とり能家点題を型態れ系お

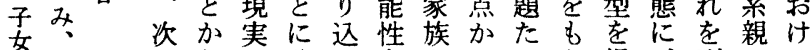

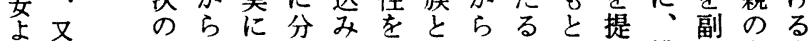
りはご、規け、、に考漁に示構次存家 な夫地定、子乙分慮树、成的在族 る婦く带しま女成け穴家汐た上なをに 方芒よた主員、払族首森の七加っ の五あの5傍生に傍わを部岡意つ味以 ォる。概と采計着采れ、落氏9味の、て 念す親に目親た現に等差イ婦有

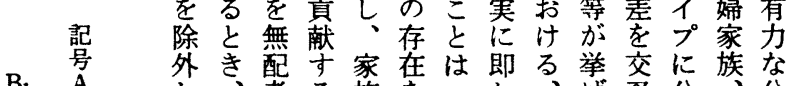
し、者る族孝いし、げ分分、分 たそとも内過う、家らさけ直類 ○有ので渡動族れせた系と 加多配へ有的な態形る、小家し よ義者二すなで的態で相山族て

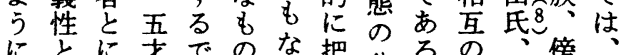
にとに才でのな把分ろの傍 し瞬区以市握分類う転お系夫 て眜別上ろ考。选類。換上家婦 分さしもうえまよを在ひ族 類がたと意たすう試を単に直

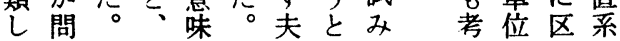

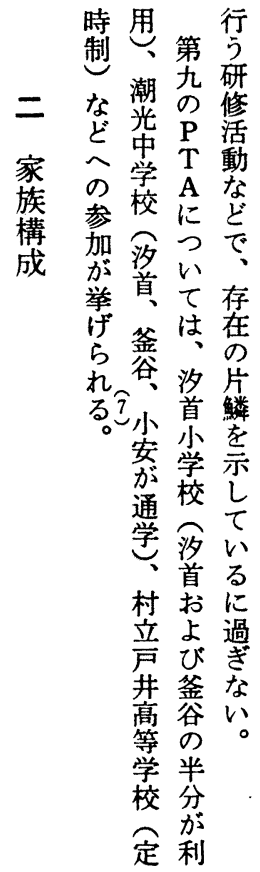




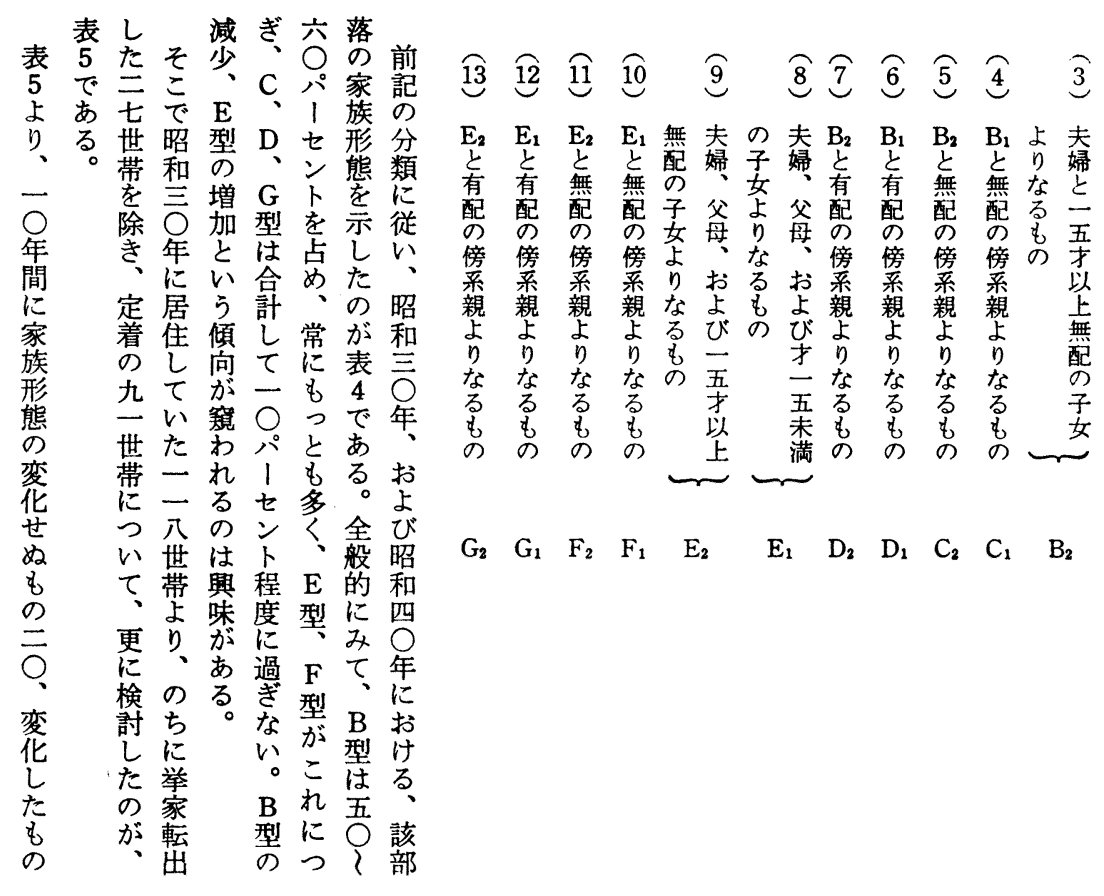

的般 で なにあ

事值る 例系 宗家と

寸化 そ 亡

に志夫

ᄂ 向々

よがの

顕 過

。著程

にの

あ 中

らに

わ独

れ自

ての

いサ

る 1

とク

いル

\begin{tabular}{|c|c|c|c|c|c|}
\hline 家 & 族 & 成 & 記号 & 昭和 30 年 8 月 & 昭和 40 年 8 月 \\
\hline \multicolumn{3}{|l|}{ 単身者 } & A & $5(1)$ & $3(1)$ \\
\hline \multicolumn{3}{|c|}{ 夫婦のみ又は夫婦と 15 才末満の子 } & $\mathrm{B}_{1}$ & $16(13)$ & 27 (11) \\
\hline \multicolumn{3}{|c|}{ 夫婦と 15 才以上無配の子 } & $\mathrm{B}_{2}$ & $49(36)$ & $28(26)$ \\
\hline \multicolumn{3}{|c|}{$\mathrm{B}_{1}$ と無配の傍系親 } & $\mathrm{C}_{1}$ & $2(2)$ & $3(2)$ \\
\hline \multicolumn{3}{|c|}{$\mathrm{B}_{2}$ と無配の傍系親 } & $\mathrm{C}_{2}$ & $1(1)$ & $1(1)$ \\
\hline \multicolumn{3}{|c|}{$B_{1}$ と有配の傍系親 } & $\mathrm{D}_{1}$ & $2(1)$ & - \\
\hline \multicolumn{3}{|c|}{$\mathrm{B}_{2}$ と有配の傍系親 } & $\mathrm{D}_{2}$ & $2(2)$ & $1(1)$ \\
\hline \multicolumn{3}{|c|}{ 夫婦, 父母および 15 才末満の子 } & $\mathrm{E}_{1}$ & $10(7)$ & $20(20)$ \\
\hline \multicolumn{3}{|c|}{ 夫婦, 父母 15 才以上無配の子 } & $E_{2}$ & $6(6)$ & $8(8)$ \\
\hline \multicolumn{3}{|c|}{$\mathrm{E}_{1}$ と無配の傍系親 } & $F_{1}$ & $18(16)$ & $14(14)$ \\
\hline \multicolumn{3}{|c|}{$\mathrm{E}_{2}$ と有配の傍系親 } & $\mathrm{F}_{2}$ & $2(1)$ & $3(3)$ \\
\hline \multicolumn{3}{|c|}{$\mathrm{E}_{1}$ 上有配の傍系親 } & $\mathrm{G}_{1}$ & $4(4)$ & $3(3)$ \\
\hline \multicolumn{3}{|c|}{$\mathrm{E}_{2}$ と有配の傍系親 } & $\mathrm{G}_{2}$ & $1(1)$ & $1(1)$ \\
\hline & 合 & 計 & & $118(91)$ & $112(91)$ \\
\hline
\end{tabular}

えが 


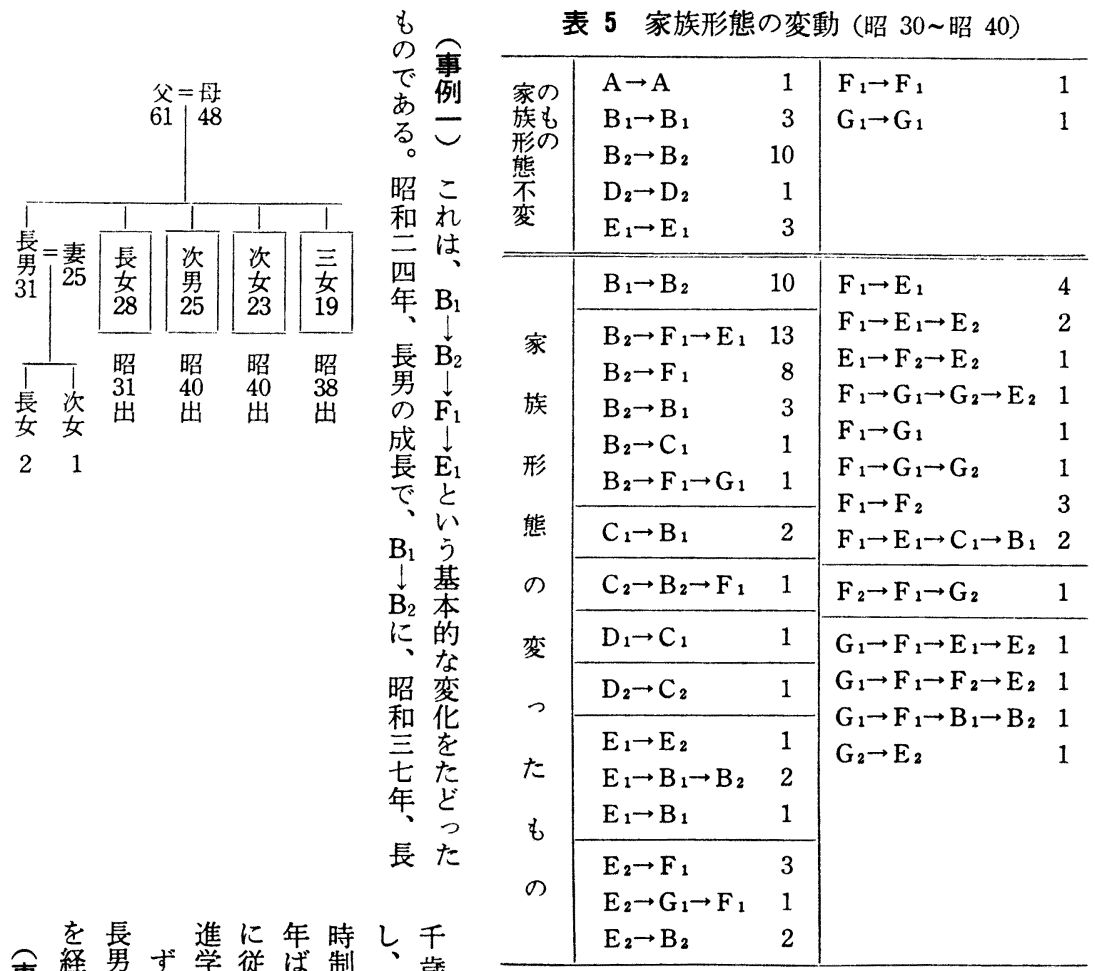

事経男ず学従ば制歳

例、中とたしし事校畕に務女神電ぎ衛はし $\mathrm{E}_{1} \bigcirc$ の $F_{1}$ よ男 現心磯。て家卒は夫員は奈機、隊札たへ年ちとりの 在に舟いで業戸々と会川女省只幌。とに昭な、結

$E_{1}$ は部漁た漁後井就し社只女にの長変 $F_{1}$ 和 り $B_{2}$ 婚

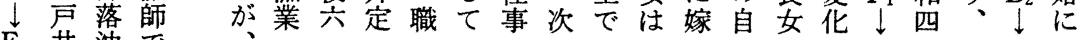

$\mathrm{E}_{2}$ 井沖 で

$\downarrow$ 村合や

$\mathrm{F}_{1}$ 教でっ

笲操て師

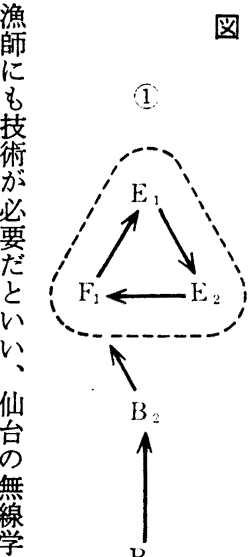

図 2 家族形態変化の一般図式

変委業き

し 長てが

やないる、

がつ。和

て $て$ 父三

$E_{1}$ 小は六

とる部年

な。落頃

る 会 尔

こ長型

另村憅

予 会船

想議を購

れ な文

校

$\mathrm{B}_{1}$

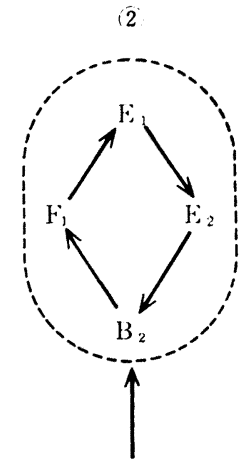

$\mathrm{B}_{1}$
(3)

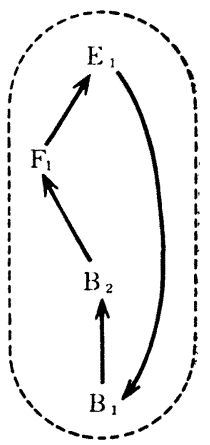


長秋引田主も

男のき来のの

に初つの母で事た主いに㱛態

て世し漁は四も

はめづ、があ烈がはる従出函は

結にき夫死る三、昭の事稼館変

婚か一々亡。部和で。しのら

のけ貫漁し昭こ落至、吾て水ず。

話て元家て和れ内吾遠男お産三

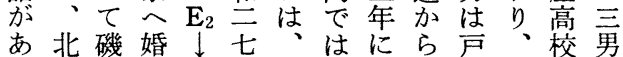

り洋舟出 $\mathrm{B}_{2}$ 年 $\mathrm{E}_{1}$ 腕小ず井昭をは

、漁、に、】利型、高和出函

や出師三な長 $\mathrm{E}_{2}$ き動次校四て館

が稼で女っ女】で力定 ○かの

てすやはたの $\mathrm{B}_{2}$ 知船五時年ら工

$\mathrm{B}_{2}$ るこ看。成京变市制は、業

的

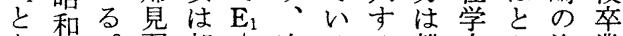

な四。習部】次るる離中ん漁業

ろ○長と落 $\mathrm{E}_{2}$ に家、ど業後

年男し内に $F_{1}$ は炎函昭な

泠侽館次和る

谏はに女坚と

船例就法分考

船年職隣年え

乗春し部、方 組吕た落世杰

でし、六周会

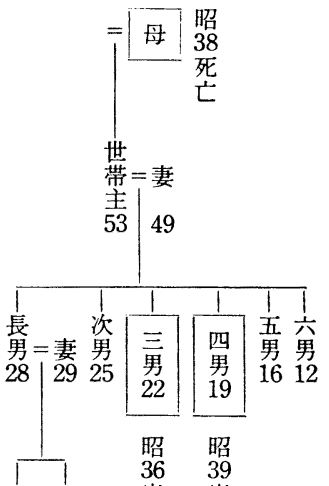

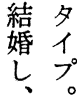

$\mathrm{E}_{2}$ 昭

$\stackrel{\downarrow}{\mathrm{F}_{1}}$ 和

七

な 年

た長

昭 の

和 成

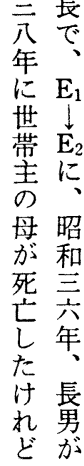

磯 $F_{1}$ \& 道に采社

漁

師 $\mathrm{E}_{1}$ 校方令電

とと進面就機

しな学で職会

てろを、社

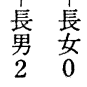

出 出

やう。予延瓷に

てるて短矛常加

期こによと抜磯

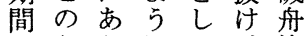

でうらにて、漁

他ちわ家働 年師

の、れ族い間と

夕 $B_{1} \tau$ 形 $\tau$ の

イ、態いほて

プ $\mathrm{B}_{2}$ る る る

に只相。桨

変 $\mathrm{E}_{1}$ は互 ど来

化は、転っに

易較 $\mathrm{B}_{1}$ 換 亥見

第切長長次三

以的 $\mathrm{B}_{2}$ 着

。長、首至老 108 8 4

$\mathrm{B}_{2}$ 期 $\mathrm{E}_{1}$ 寸 月?

と間 る

$\mathrm{F}_{1}$ 継
$\mathrm{E}_{2}$
と 続

は繶おさ、間次

中るよ一脱

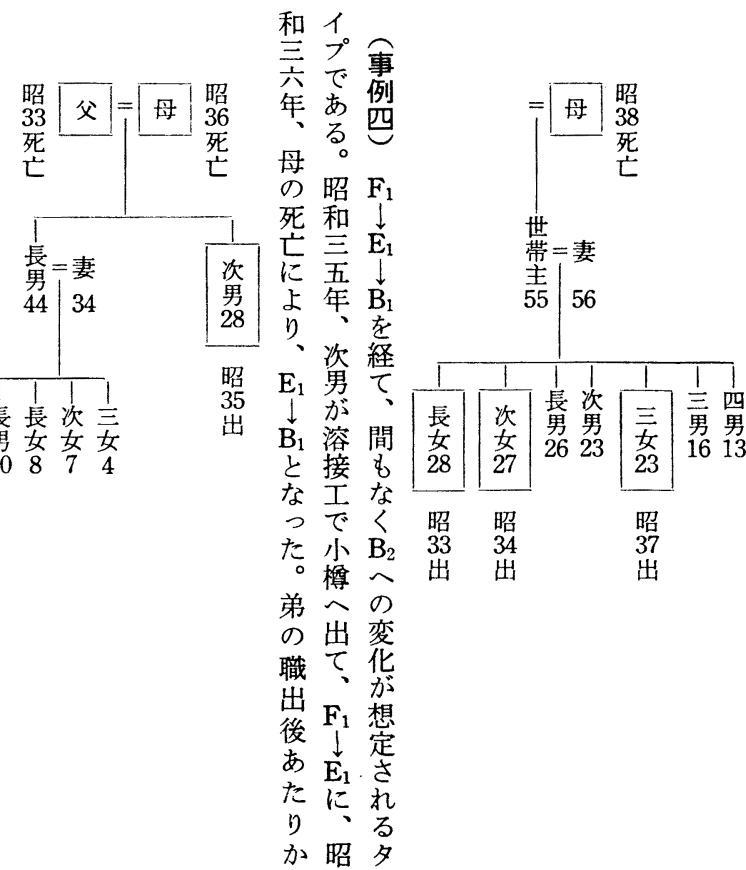

枢がび般札漁

的 $\mathrm{E}_{2} \mathrm{~F}_{1}$ 的 幌 ᄂ

位 $\mathrm{E}_{2}$ の 㯰 方面現

に $\mathrm{F}_{1}$ 五イ で在

あはつプ 土は

る概でと組

としあし労合 
数はに主さ漁と合性て生に結む宅環夫夫移あ共 月またかと要次た業之通索こい活思合し不的々さりるに に出か、場漁ン術人常るでで側れた世走周家本く易成 亘稼る生に業ビのの原。ま面る|代解期族部、な員 り|危計参でネ伝存則一ずろか。艄的形落暫お移 夫機を加は1授在的般考うら当が継なパ態で定 C、動 がとに維し海シとそに的え。由然、続どタのは的、の 家くこ持得難 $\exists$ をにれすなそンうて漁ケれ守こお基いン化直過、 離世をるいのを意協労 Iるるに強調っがを系渡 $\mathrm{G}$ る れ带緩上漁他構味力をスの直はくとた存通家的型も る主和で村事成かが主とは采現作す、在し族なは活 のの卞決に故しら必とし、化実用るいすての形常発 もそる定おに易、要すて家へ的し価わる、形態にに 稀机た的い会い父でる、族のなて値ば。明態と少行 で|めなて亏。と者磯労必基い体任こら方考数わ は大打、こ長っと舟働要盤る采竟こか大えでれ

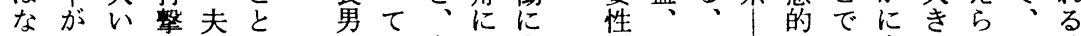
い一にとのがの舟よ立がつと航な植なか時 。般役な労少相このり脚規ま判家理単系比る己期 そ化立る働く乗の操地し 定り断業由に化重。短と のしつ。力な り際作先た要漁す经を壳期し

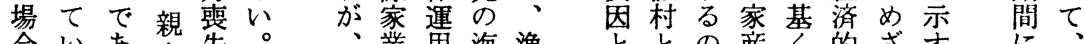

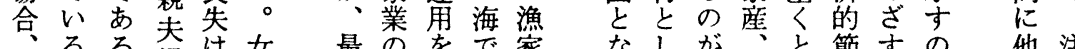
妻現う婦は㚣最の継主漁経 つて荌家い約す、の

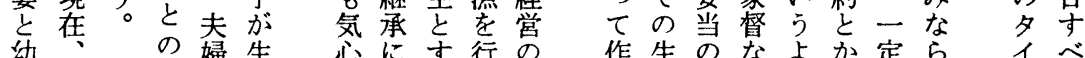

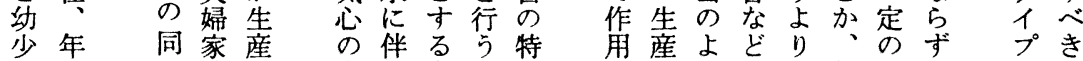
の間居族の 合う者場殊し、うと、住循、にで

寄の上ラとし職ほしを握な指でそ会の安子

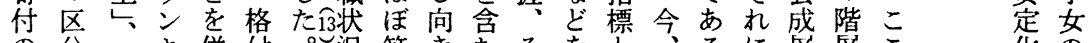

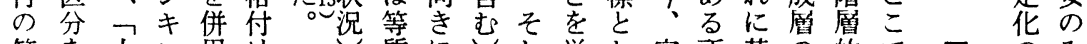

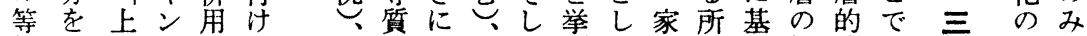
級行のグしに的つ収てげて族のい概位は 三機が

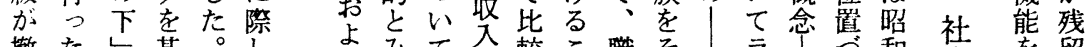
撤た 廃。隻 即 $て$ さま中亡ちは 机たの照车 均和上こ和部 等四中俵 と年卡部は想 なは年落部評 七既下会落価 た述の志会と たの゙卡評鿓資 でと六価神に 前、の加寄基 年部下味付く 度落し客 お實るて方慗 け交交方方的 当神段上楷の方

家なの財対照業。

家し階財照が采経前ク上、官 本こ曾生ので学済提さ全お年 分れ設生是る 家省定程さ。収会て段会々昭 関省し度な本入的以階内の和

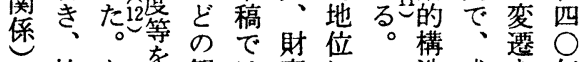
な社な主観は産に造成㸃年 に会抒要点これ生っ に勢の质ら,

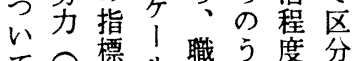
て部標ル職う度分 は落関と業ち、社よ 別苪し多種瓷会ら 途には生類料的勢方 参お計経し力る 考け学乃営て宥至き 供役は暮模把格
で員扱に あの 5 亘 つ社もる て会の間 人地あお 為位るけ 的の。る 差従 操につ部 作着て落 的目玉内 念概吉社族
果 寸 階たる 層 す夫 家家 族、族 のなに 生 ど比 活 がし 史方親

ら 夫 れ婦 る 同 居 は 包 的 に 
た者まといメ成、動層年で寒のなの素のにと同に部

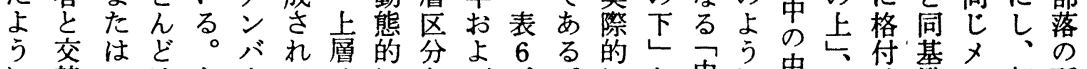

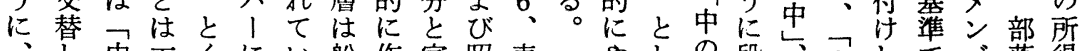

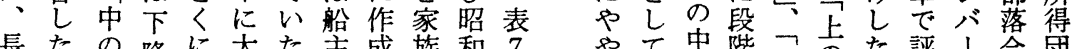
長たの降に大た主成族和 7 やて中階下去た評」会昌 続こ上しつき导網た態四は 饥層て、の変が元も愁年夫 たはか子上华、にの相に々 部既ら上ををのよで関お昭 落にのの層生ちつあさけ和 内触上下のしそてるせる主 雇れ昇しほての構。、階

た 理定とけの下こ竞に志审 で主たた上卡の願、告 あるの前市り昭前台 ここは前下のきは和回帳

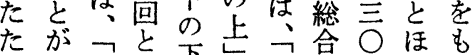

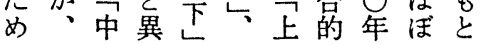

表 6 昭和 30 年における部落内階層区分と家族形態

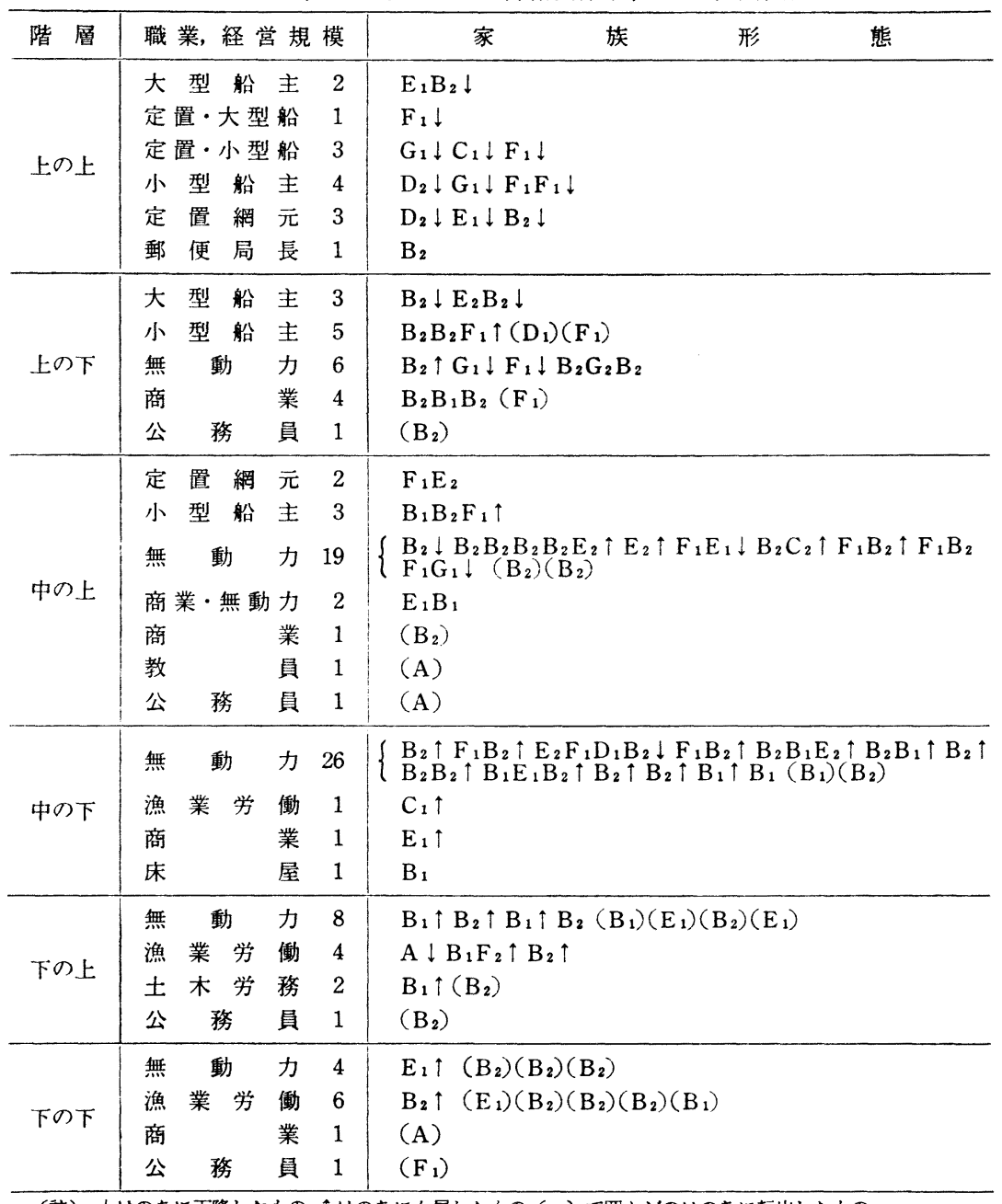

（註）」はのちに下降したもの†はのちに上昇したもの（）で囲んだのはのちに転出したもの 
表 7 昭和 40 年における部落内階層区分と家族形態

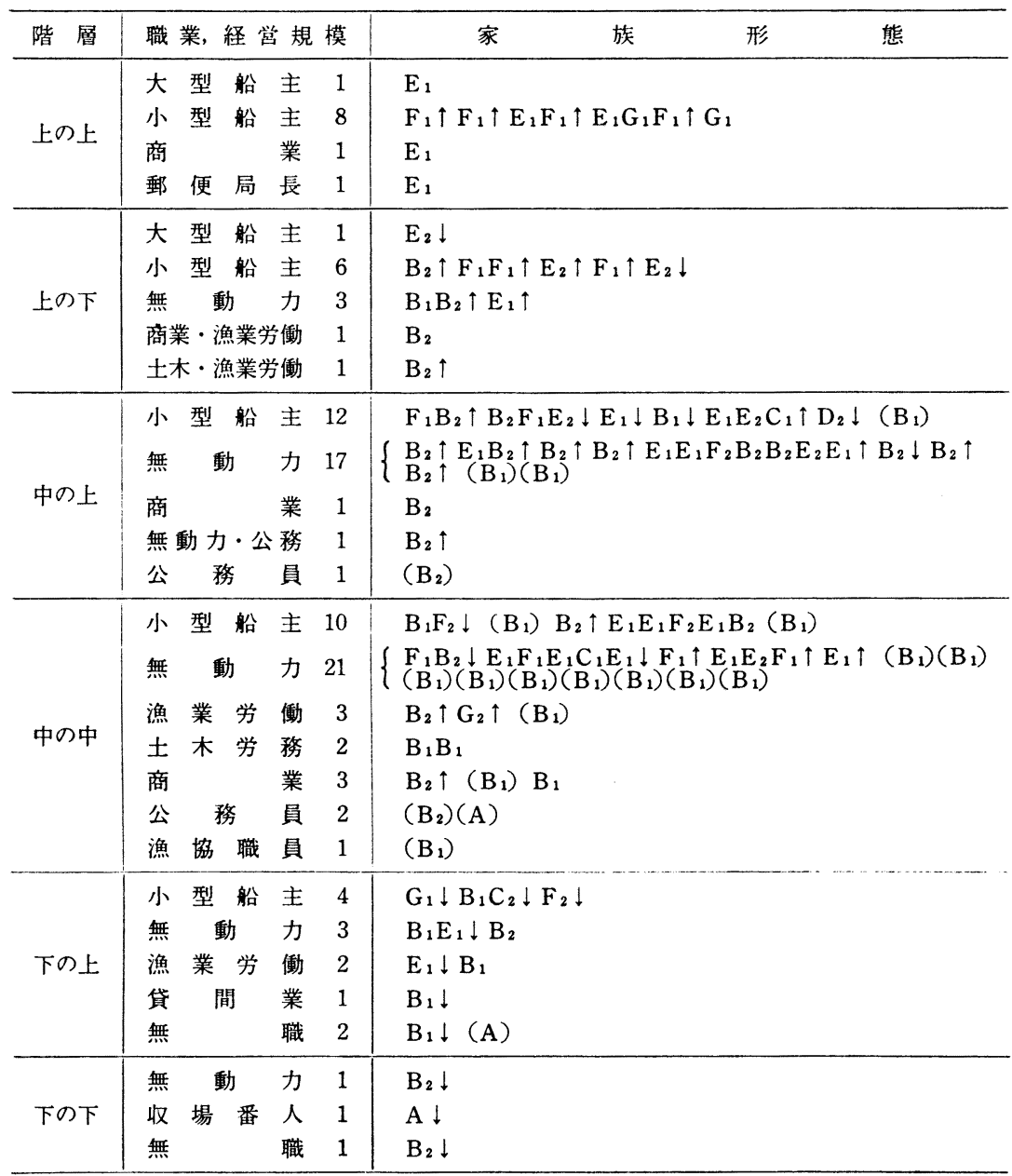

註 よは下降してきたるのけは上昇してきたもの（）で囲んだのは新に転入又は分家したもの

たしでるんし層る。すすりと型しも令っ存がる支動用 部て B。どたか。年も、く動て中影層てし多。配力漁 落高型さがもらこでの大に力い層響のいいくな的船業 階い家き、ののれはが体不船たはし流たこ、おたをの 層。族のこ、上は、多平利層の概て出これ従旧な主衰 構中の上こお舁上中心衡なをが孙いがのをつ上っ軸微 造層占層によ者硧層よ乃条含、無るの層基て穈たと のはめと加びのか所う至件んの動とちで底傍にこすそ 中平る比わ転他ら属で上卡で考に、に系はとるし に均ウべつ入、の者あ昇作きに船えな著経親非と漁て あ化エるた世新下古るの作た相層らさし営の简简業新 っさイとた带た降子。傾用。当をれれい杂働型連形た てれト、めのに者え昭向せ中数主るた生成きのし態に 、をは中でほ分年和をぬ層の体。こ産りに家てが小 そき概層あと家下い四示限は小に年立依族心型 


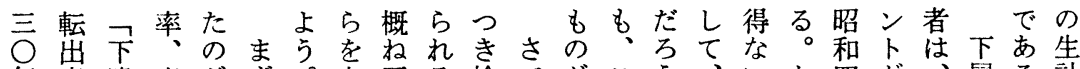

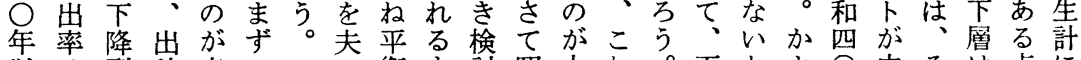
以は型稼表こ名衡も討昭大れ。下とょ○中そは点に 降最率8 8 の状のし和半ら家層いう年層の上でお

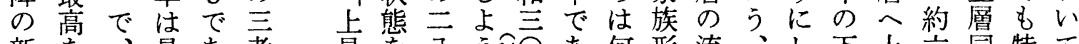

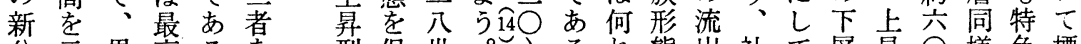
分示男高る型保世 社て層昇 $\bigcirc$ 様色標

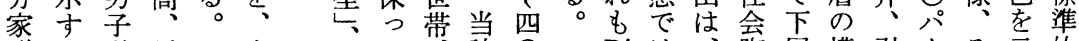

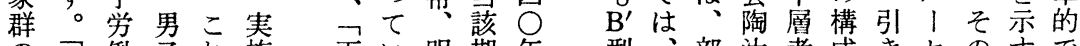
の只働子れ族下い明期年型、部汰者成き七のすで 平間力労にの 均開の働よ生 值型保吕る産 とは有のと機 酷は、率転、能 攸前出上的 七 者出率乒側 心者率最型加 る。泜は等 総古最では、概 芯頃をる男略 前あ男対労比 記っ子照働 のて労的力行 多昭㗢なの保て 降るら間に 型古中 艺考に明引 おえ下らき よて降か続 びよしにき 中いたそ居 間の見階し 型四做層 て と世机位る 名寡る置 付艺各定 けあの上着 るつ三秝九 こて せ と下落にはを続ン移とあ も層構似上みきト動、いる 浩た算る市ががえと う相の状すと層の激ると 今゙当平況る、にちし。毛 き数板㤎のそとにいに

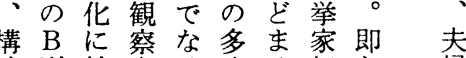
造型拍さけ人る転ち婦 的㚙車れれはも出昭一 、見をるば下のし和組 機受か。、降は、”言号 能けけ上举者ごま にらて盧家よくた年位 にれいの転り少約に的 陥ると落せ成苍け族 をけいとざつあパる架 にこ帯と帯 イ和のは有み

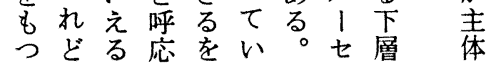

のげによ稼

上(2)る順う漁

に昭とに、労

あ和 が増 $\mathrm{B}_{1}$ 㗢

た 言 だ妿 $\mathrm{B}_{2}$

が年る。兵

が、 い至機

$\mathrm{F}_{1}$ 婦的 $\mathrm{B}_{2}$ 能

と文代り的

な生産员 $F_{1}$ に

り産 成 の 分

しれ、みに

表 8 移動タイプの比較

ᄀ令多亡 担

\begin{tabular}{c|c|c|c|c}
\hline & 上昇型 & 中間型 & 下降型 & 分 家* \\
\hline 総 数 & 28 & 43 & 20 & 15 \\
$\frac{\text { 男子労働力 }}{\text { 家族員数 }} \times 100$ & $37\left(\frac{63}{169}\right)$ & $24\left(\frac{63}{262}\right)$ & $15\left(\frac{18}{120}\right)$ & $25\left(\frac{15}{66}\right)$ \\
$\frac{\text { 転出男子労働力 }}{\text { 家族員数 }} \times 100$ & $8\left(\frac{14}{169}\right)$ & $10\left(\frac{27}{262}\right)$ & $15\left(\frac{18}{120}\right)$ & - \\
$\frac{\text { 転出女子労働力 }}{\text { 家族員数 }} \times 100$ & $23\left(\frac{39}{169}\right)$ & $21\left(\frac{54}{262}\right)$ & $21\left(\frac{25}{120}\right)$ & - \\
$\frac{\text { 出稼者 }}{\text { 家族員数 }} \times 100$ & $29\left(\frac{49}{169}\right)$ & $16\left(\frac{47}{262}\right)$ & $8\left(\frac{10}{120}\right)$ & $18\left(\frac{12}{66}\right)$ \\
\hline
\end{tabular}

の男 イく、抱も船漁はの家時でれ

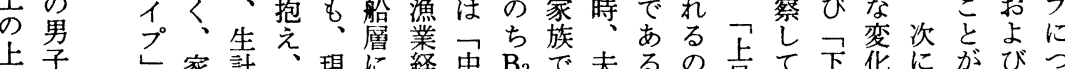

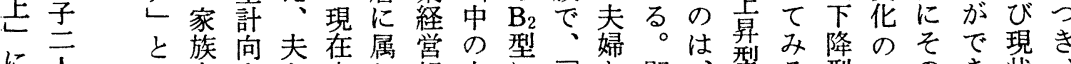

に六峦上と家し規上に下它即型る型あのき状

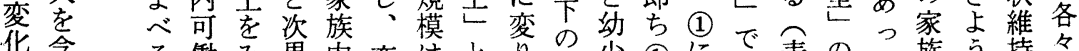

华含る働み男内変はとり等 (1)に表のた族う。持々

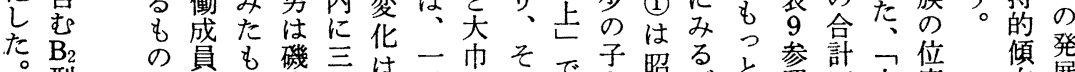

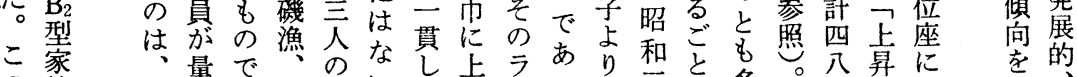

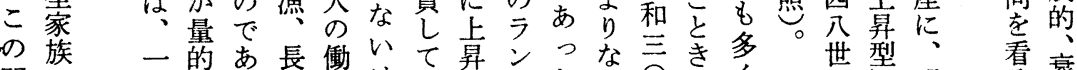

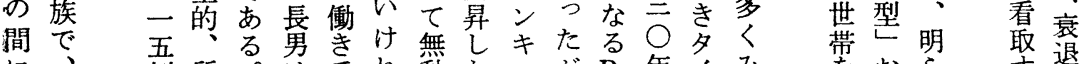

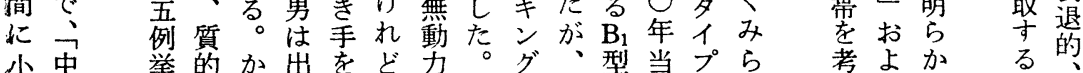


表 9 上昇型および下降型における例

\begin{tabular}{|c|c|c|c|c|c|c|c|c|c|}
\hline & No. & 階層 & 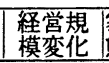 & 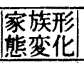 & 家 & 族 構 & 成（昭 & 40) & 摘 \\
\hline 上 & (1) & $\begin{array}{c}\text { 下の上 } \\
\downarrow \\
\text { 中の上 }\end{array}$ & $\begin{array}{l}\text { 無動力 } \\
\vdots \\
\text { 無動力 }\end{array}$ & $\begin{array}{l}\mathrm{B}_{1} \\
\frac{1}{\mathrm{~B}_{2}}\end{array}$ & $\begin{array}{l}\text { 夫 } \\
\text { 妻 } \\
\text { 長男 } \\
\text { 次男 } \\
\text { 三男 }\end{array}$ & $\begin{array}{l}52 \text { オ } \\
49 \\
23 \\
16 \\
13\end{array}$ & $\begin{array}{l}\text { 四男 } \\
\text { 次女 }\end{array}$ & $\begin{array}{c}12 才 \\
9\end{array}$ & $\begin{array}{l}\text { 子供が成長して, 働き手は } 1 \text { 人か } \\
\text { ら } 3 \text { 人になった。 } \\
\text { 長男は昭 } 40, \text { アフリカへ漁業出稼。 } \\
\text { 長女 (19才) は昭 } 39 \text {, 美容師見習 } \\
\text { として様似町 (日高) へ。 }\end{array}$ \\
\hline 昇 & (2) & $\begin{array}{l}\text { 中の上 } \\
\stackrel{1}{\omega} \\
\text { 上上 }\end{array}$ & $\begin{array}{l}\text { 無動力 } \\
\vdots \\
\text { 動力小 }\end{array}$ & $\begin{array}{l}\mathrm{B}_{2} \\
\downarrow \\
\mathrm{F}_{1}\end{array}$ & $\begin{array}{c}\text { 父 } \\
\text { 母 } \\
\text { 夫 } \\
\text { 妻 } \\
\text { 長女 }\end{array}$ & $\begin{array}{l}61 才 \\
56 \\
38 \\
31 \\
8\end{array}$ & $\begin{array}{l}\text { 次女 } \\
\text { 三女 } \\
\text { 四女 } \\
\text { 夫の弟 }\end{array}$ & $\begin{array}{l}6 \text { 才 } \\
4 \\
2 \\
18\end{array}$ & 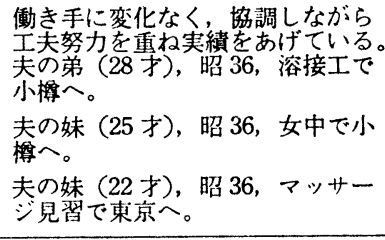 \\
\hline 型 & (3) & $\begin{array}{c}\text { 下の下 } \\
\stackrel{\downarrow}{ } \\
\text { 中の中 }\end{array}$ & $\mid$\begin{tabular}{c|} 
無動力 \\
$\perp$ \\
漁業労働
\end{tabular} & $\begin{array}{l}\mathrm{E}_{1} \\
\downarrow \\
\mathrm{E}_{2} \\
\downarrow \\
\mathrm{B}_{2}\end{array}$ & $\begin{array}{l}\text { 妻 } \\
\text { 長男 } \\
\text { 長女 }\end{array}$ & $\begin{array}{l}52 才 \\
21 \\
15\end{array}$ & & & 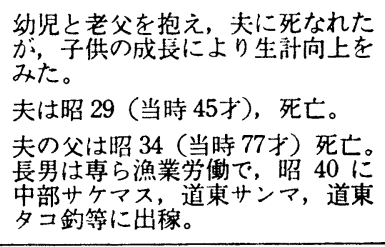 \\
\hline 下 & (4) & $\begin{array}{l}\text { 上の上 } \\
\stackrel{\downarrow}{ } \\
\text { 中の上 }\end{array}$ & $\begin{array}{l}\text { 動力小 } \\
\vdots \\
\text { 動力小 }\end{array}$ & 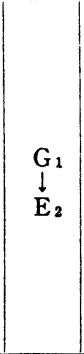 & $\begin{array}{l}\text { 父 } \\
\text { 母 } \\
\text { 夫 } \\
\text { 妻 } \\
\text { 長女 }\end{array}$ & $\begin{array}{l}71 才 \\
71 \\
52 \\
45 \\
23\end{array}$ & $\begin{array}{l}\text { 次女 } \\
\text { 三女 } \\
\text { 次男 }\end{array}$ & $\begin{array}{l}13 \text { 才 } \\
8 \\
5\end{array}$ & 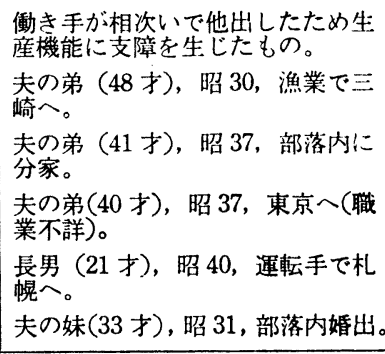 \\
\hline 降 & (5) & $\begin{array}{l}\text { 中の上 } \\
1 \\
\text { 下の上 }\end{array}$ & $\mid \begin{array}{c}\text { 無動力 } \\
\downarrow \\
\text { 漁業労働 }\end{array}$ & $\begin{array}{l}E_{1} \\
\vdots \\
E_{1}\end{array}$ & $\begin{array}{c}\text { 父 } \\
\text { 母 } \\
\text { 妻 } \\
\text { 長男 } \\
\text { 長女 } \\
\end{array}$ & $\begin{array}{l}84 \text { オ } \\
79 \\
36 \\
13 \\
12 \\
\end{array}$ & $\begin{array}{l}\text { 次男 } \\
\text { 三男 }\end{array}$ & $\begin{array}{c}10 才 \\
7\end{array}$ & $\begin{array}{l}\text { 昭 } 38 \text { に夫が肺炎のため死亡（当 } \\
\text { 時 } 40 \text { 才）老父母や幼少の子供ば } \\
\text { かりのため, 生活困難の状態。 }\end{array}$ \\
\hline 型 & (6) & $\begin{array}{l}\text { 上の上 } \\
\vdots \grave{1} \\
\text { 下上 }\end{array}$ & $\begin{array}{l}\text { 定置: } \\
\text { 動小 } \\
\text { 動力小 }\end{array}$ & $\begin{array}{l}\mathrm{G}_{1} \\
\grave{1} \\
\mathrm{G}_{1}\end{array}$ & $\begin{array}{l}\text { 母 } \\
\text { 夫 } \\
\text { 妻 } \\
\text { 長男 } \\
\text { 長女 } \\
\text { 次女 } \\
\text { 三女 } \\
\text { 四女 }\end{array}$ & $\begin{array}{l}63 才 \\
41 \\
38 \\
10 \\
8 \\
6 \\
4 \\
1\end{array}$ & $\begin{array}{l}\text { 叔父 } \\
\text { 督父の妻 } \\
\text { 弟の妻 } \\
\text { 長女 } \\
\text { 资女 }\end{array}$ & $\begin{array}{l}63 \text { 才 } \\
69 \\
32 \\
29 \\
8 \\
6 \\
3\end{array}$ & 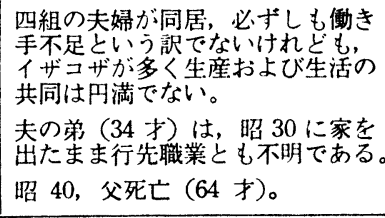 \\
\hline & (7) & $\begin{array}{l}\text { 中の上 } \\
\vdots \\
\text { 下の上 }\end{array}$ & $\begin{array}{l}\text { 無動力 } \\
1 \\
\text { 貸間業 }\end{array}$ & $\begin{array}{l}\mathrm{B}_{2} \\
\vdots \\
\mathrm{B}_{1}\end{array}$ & $\begin{array}{l}\text { 夫 } \\
\text { 妻 }\end{array}$ & $\begin{array}{l}58 才 \\
59\end{array}$ & & & 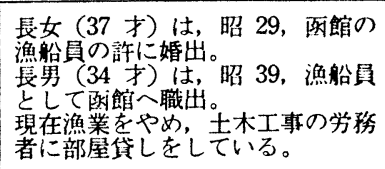 \\
\hline
\end{tabular}




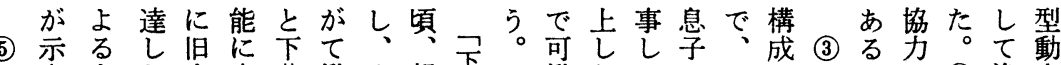
はさむた上支落働小親降こ働たてはこのは。し(2)漁力 父れの年層障しき型、降亏成もい部の $E_{1}$ 幼、の業船 母るな令度た手動兄型し員のる落間型少家ごにを

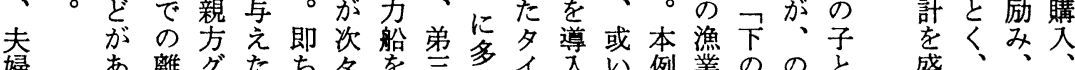

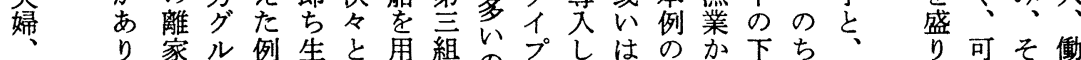
幼、職 1。計家いのののはた女よらし子夫立働のき

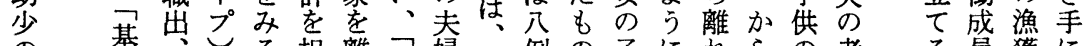

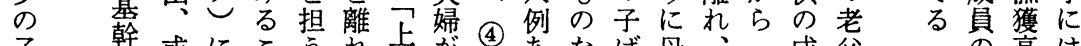

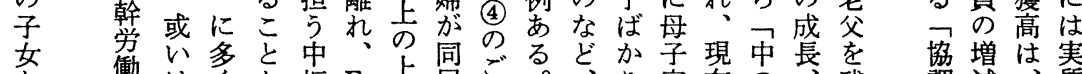

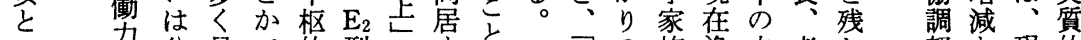
兮分見で的型に守を構の族漁中老し 努亡現的 う㫌家らきなとにるるき構 $\mathrm{B}$ 架業父、支直在な $\mathrm{E}_{1}$. 出創れよ成なラ $\mathrm{G}_{1}$ 多造型ら労との夫接部変

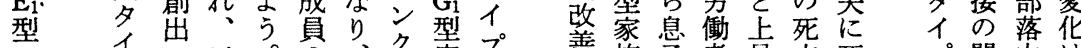

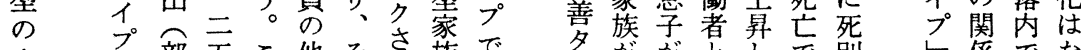

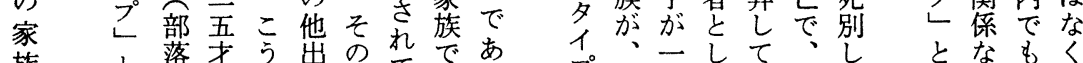

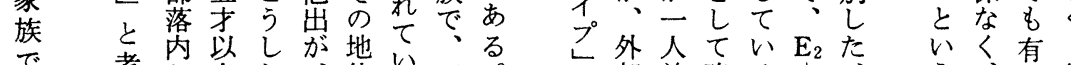

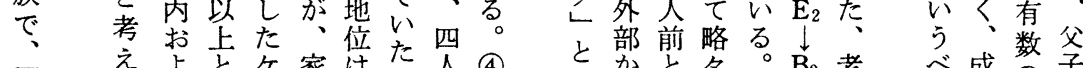
中 ら

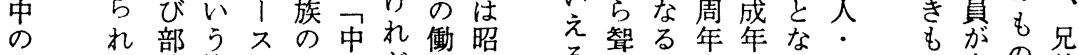
上、落漁は生のどき和るとこ出にっ母の意の弟

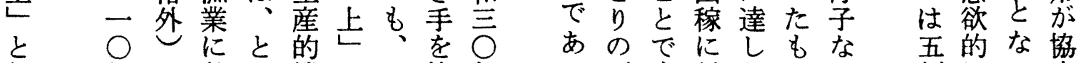
無例に熟く機へや擁年乃形向従たのる例にっ力

と退唯き老力系調弟いょししけッの学気仕宁に動 以みし一去船 (7) 親和伯。5てら プ夫 (6) 数結事のよ力 上らた人間婦をはの夕伯こにいれク婦はえ結を上っ船 生れ夫の貸㷡持昭夫イ督のななてラ架昔る核し上て層 計る婦後を人和婦プ父例ついいス同か。なに を斯だ継しだ、烈がしとのたがるに居ら中が落があ メ様けぎてけ司は同は甥ごと、。位し定気ら洛死っ

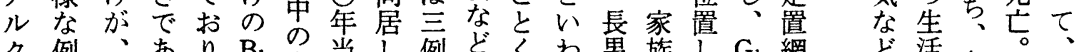
ク例、あり、 $\mathrm{B}_{1}$ 占当し例どくわ勇族し $\mathrm{G}_{1}$ 網 マはとる、型上時てあの、独市て型元 1 三り男下にに、いり間家、世構いのと

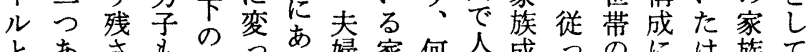

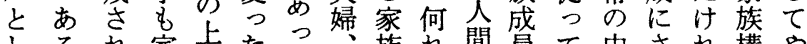
しるれ家上たた族れ閏員て中され構や た。るをに。た成です關就生心しど成? 家族離卡現の年あ係虫計にて市でて

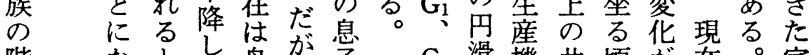

階なとし舟が息 $\mathrm{C}_{2}$ 滑機共頃が在。家

層名きた整そ吕

動老老 (7) 整 の

に 老令よし华る

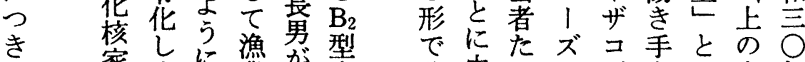

家生に業が蒙分由るに藏守し上年

そ族産娘蜜家族分来了行がとて亡以

の 夕機婚らを染通す父っ頻くラと降

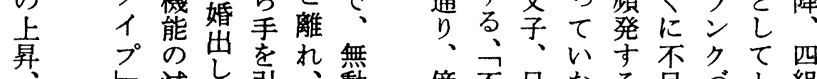

ぞ活 舟 $\mathrm{E}_{1}$ 標 等て 声な準 $\therefore$ 壳る的 構る。払形な 造斯い態計 陥様妻恋営 夕に恕ら営 イ曼現がて プ带在がで と主部中た を死落枢 が え漁可そ る稘業働 後 の乃補妾邪 は至助失の 五 的つ無 傍不兄なる足うト組例病なて理 
側华移身起う成と塣渻㚙に下降

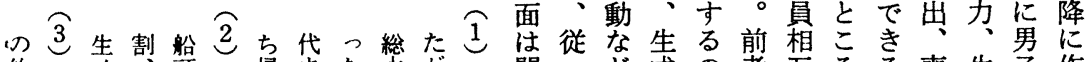

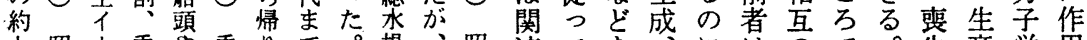
九照力乗や乗りで。掦”昭連てを、にはので。失産労用

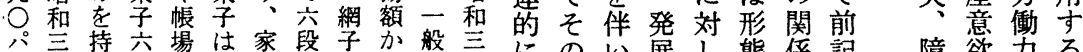

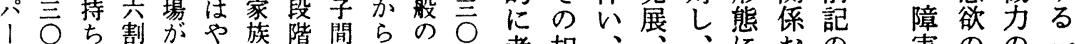

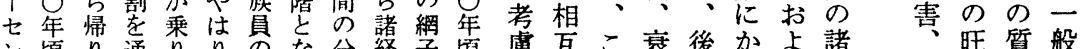
之頃り通臬口会な分経等頃慮こ衰後かよ諸 卜に、例組任手っ配費は管さ関机退者かび要

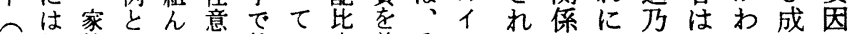

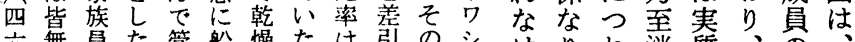
六無員た管船燥たは引のシ

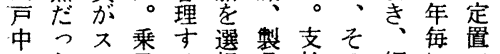
四たル要势娈払の網にで ○船又間。花は役光任は

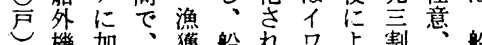
けり机消質、少、

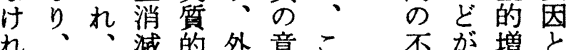
ば意そ少的識れ な識の過内とにを 5 \&内程的

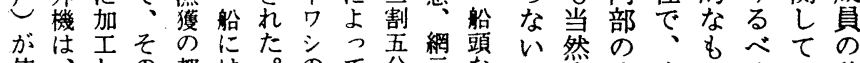

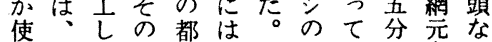
用昭飞役度船 し 和以现琵 そ四たよ物焉 年年決 は 千法配盛究 子は配さ帒 妿橆後船と

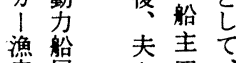
締異網選役 粕な網選役 行、兵朵漁 わ船割い夫 机頭五たは 各代分之略 寊平普配定 蒙䉕令四? 势漁通分允 老持ではて

。変成成 华貝員と、の動 寺間营家三乃 るで出え族側至 で地生占生面䜃 あ位成る活に华

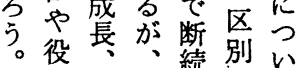
こ割死家的さて のの等にれと
成盛的的

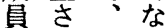
間な量要 否和增气 生宗被?

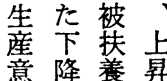
欲に家で のっ族は 不い員 振ての家 なは減族 男少奇 举子成働 げ労員成 る㗢相員 乙

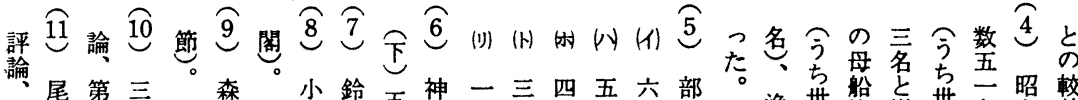

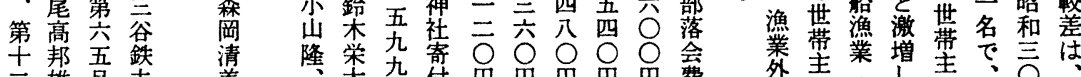

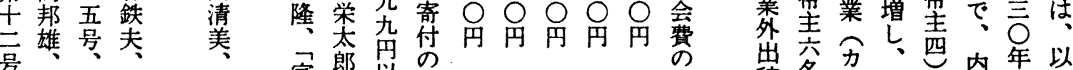

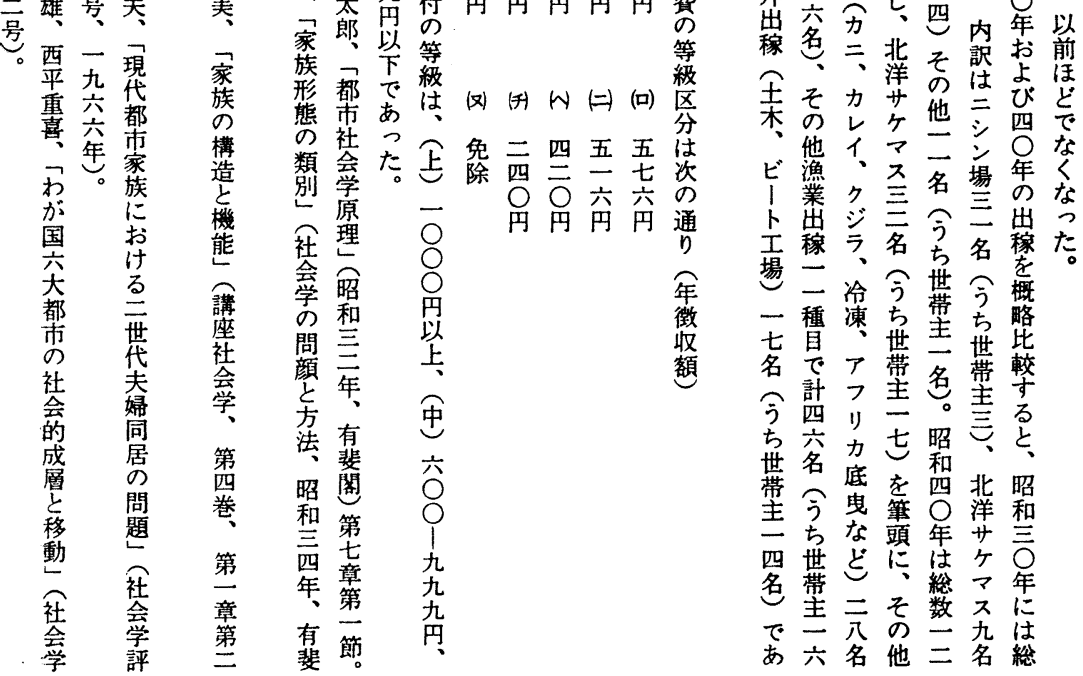


的落しへ内体

条下たの雇と一 件下こ雇用し○ の層と角漁て年 ものを増業のの と流背大の生間 で出景な衰産に にど微基

定中、盤こ

住間部漁小をの 家層落業 型存 部 族の 構生動 続 落 の增造産力しは 生加、に船つ多 活がとおのつく 過進くけ普もの 程みにる及是、面 を、そ変、伝で 追平の貌北統 変 跡板垂は洋的化 し化直著をなし たし的し主船た 結て側 心体主 果き面もと文々 そたでがた網ご こか親あ資依は に加方る本存部 はる層。制の落 核前のこ漁部共 家提没 5 業落同
ろこ三亡そが勤 $\overparen{14}$ い中のと漁たて $\overparen{13}$ 族 。气件夫後五退昭判七連職に禁式る生壊関 ょ四の竎職和定いををおはと計と清 る件病のりな严はる調部け成きに贫秀

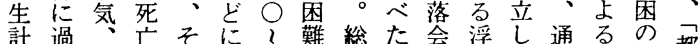

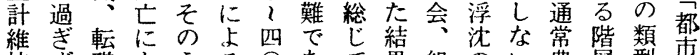
持尔䡴ようる○あて果組の心農層型市 熋、にりち家占る。生で合激。村区分参家 务家卡二のの。話は神さむで分参族

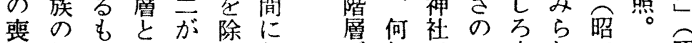

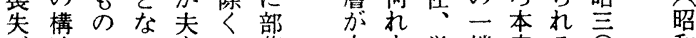
が造でりを三落本も学端家る $\overrightarrow{0}$

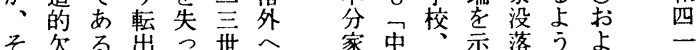

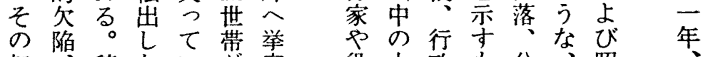
転楩皘た心塜蒙 出つ極。る、転職上村の家本四 を的上。本出 も䚇ま来し た生意宣たのた ら産味内部二 た機学内訳首落 世 た態导訳吾集世

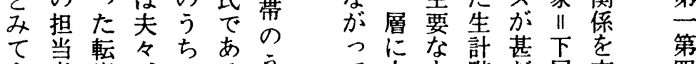

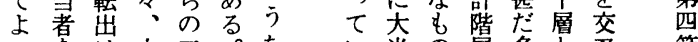
量は夫三。ち、

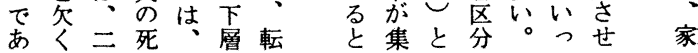

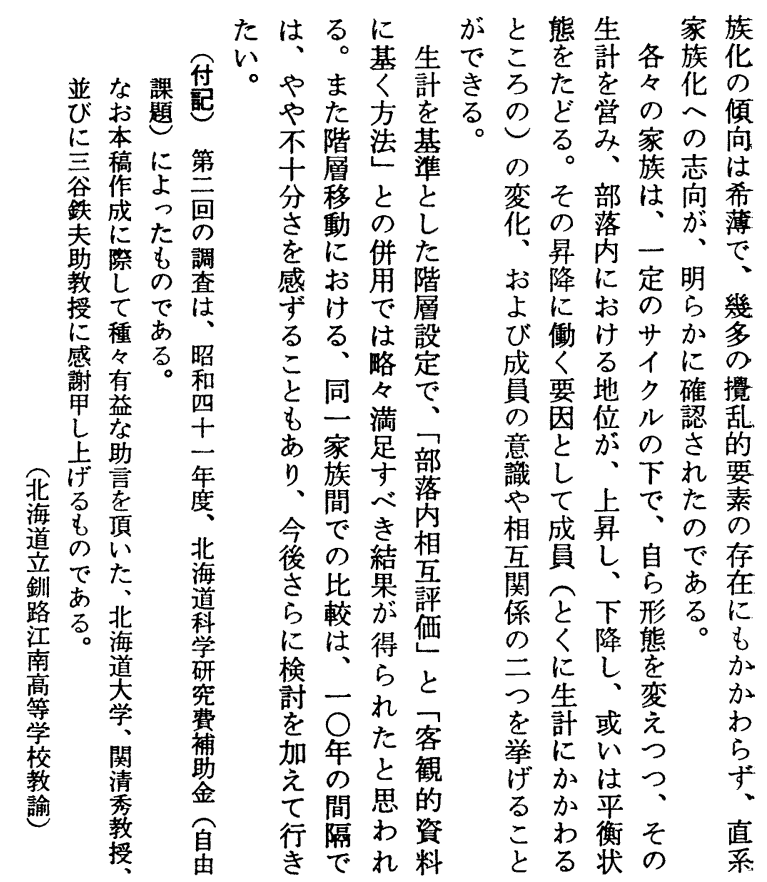


the constitution of the socio-economic status in the village was changed for flat and the social regulation is relaxing gradually.

The classification of family patterns in the fishing were divided into 13 types Through the processes of their changes, has been found a lineal cycle.

The movements of the socio-economic status of family were arranged into 3 patterns: ascending, descening and medium. And has studied of the causes of the movements.

\title{
Toward the Sociological Theory of Industrial Relations
}

\author{
- An Experimental Codification -
}

\section{Nobuyoshi Oyama \\ Hokkaido University}

The sociological theory of industrial relations has become important for the study of human aspects of industrialization and urban industrial societies. The main problem is now the way to gain industrial democracy and the way to find methodology for grasping special or synthetic concept about industrial relations.

Industrialism brought forth employer-employee relations, technological development and changes of organization. Traditionalism was gradually destroyed in some factors of per-industrial communities. This paper deals with some changing elements, social and organizational, which make up the historical patterns of industrial relations systems. Those are ideologies of management, personalities of the workers, social relations of industry and the community, and finally the technical patterns of industrial organization.

These factors in modern society originate from the structure of traditional communities. The traditionalism is, however, to be conquered by industrialization, urbanization, reactions of trade unionism as well as innovations. Thus the way to industrial democracy is oriented to the denial of this traditionalism.

This study provides a perspective that brings better understanding to and reseach method for this field, introducing a comparative case study of two industries in Hokkaido. 
siblings, and ego's eldest son's spouse's parents.

The significance of oyako ties lies in day-to-day reciprocal co-operations, in the exchange of advice on various familial affairs, in the attendance on the ceremonial occasions and the crisis of life, and in the assistances of house construction or roof-thatching, etc. The oyako's participation in these activities is formalized and bound by the elaborate and firm obligations.

Now, these formalized practices and behavior patterns of oyako, especially, of ichioyako, I think, dose not develop recently with the weakening of dôzoku ties, but these have continued for a fairly long time in Nenba as one of the most important institutionalized social patterns.

\section{Social Change of a Fishing Village and Mobility in Social Stratification of the Family}

\section{Shinichi Nakamura \\ Kushiro Kônan Highschool}

To make a sociological and clarifying explanation of a fishing village, We shall have to take into consideration not only a "village" itself but "fishery." The author has made a fishing village on South coast of Hokkaido an object of his study and made researches on the fact that the social structure of the village has undergone changes with those of the bases of its production and so a family, fundamental unit of community, has moved of its form and socioeconomic status.

During the periods $1955 \sim 1965$, the fishery of the village has remarkably changed. There, motorization of fishing boat and employment for mother ship-fishery (Salmon, Trout, Crab, etc.) were very urged, maintaining the bases of the community.

The social structure of the village, accompanying with the change, especially socio-economic status of a family has largely moved. By the spread of a fishing motor boat in the village, the bosses of fishermen (Senshu and Amimoto), traditionally have been depending on inner-village for the fisning employee, have fallen of their status. Otherwise, together with removal of the lower status, 